\title{
RELIGIÕES NO BRASIL E RELAÇõES INTERNACIONAIS NO SÉCULO XXI
}

\section{RELIGIONS IN BRAZIL AND INTERNATIONAL RELATIONS IN THE XXI CENTURY}

\author{
Alberto Pereira dos Santos \\ Universidade do Estado do Rio de Janeiro (UERJ), Rio de Janeiro, RJ, Brasil, albert.geo@uol.com.br
}

\begin{abstract}
RESUMO
Após o fim da Guerra Fria com a desintegração da União Soviética que representava o perigo do "bloco comunista", os paradigmas predominantes no estudo das Relações Internacionais entraram em crise. Desde o Tratado de Paz de Westfália (1648) o poder religioso havia sido marginalizado nas análises do poder no espaço internacional. Contudo, um novo "inimigo" para o "Ocidente", o Islamismo, despertou a atenção de estrategistas em política externa dos Estados Unidos. Nesse contexto, a religião passou a ser considerada como elemento de análise nas relações internacionais. Esta reflexão livre busca contribuir para o debate acerca do papel da religião nas relações internacionais e sobre o papel do Brasil neste cenário no século XXI.
\end{abstract}

Palavras-chave: relações internacionais; religiões; geopolítica; Brasil; geoética do apoio mútuo.

\section{ABSTRACT}

After the end of the Cold War with the disintegration of the Soviet Union that represented the danger of "Communist bloc", the prevailing paradigms in the study of International Relations in crisis. Since the Peace Treaty of Westphalia (1648) religious power had been marginalized in the analysis of power in the international space. However, a new "enemy" to the "West", Islam, attracted the attention of foreign policy strategists in the United States. In this context, religion came to be regarded as an element of analysis in international relations. This free discussion seeks to contribute to the discussion about the role of religion in international relations and about the role of Brazil in this setting in the XXI century.

Keywords: international relations, religion, geopolitical, Brazil; geoethic of mutual support.

Artigo recebido para publicação em outubro de 2014

Artigo aceito para publicação em fevereiro de 2015

\section{INTRODUÇÃO}

Na Rio+20 (Conferência das Nações Unidas sobre Desenvolvimento Sustentável), entre outras coisas, nos chamou a atenção o discurso do presidente do Irã, Mahmoud Ahmadinejad, disse ele:

Diante da crise econômica e moral, a ordem internacional precisa ser redesenhada, com base em uma visão holística, e que se baseie em um Deus único, para servir tanto às necessidades materiais quanto espirituais dos seres humanos. No mundo futuro, a justiça e a compaixão devem ser institucionalizadas e tomar o lugar da inveja e do egoísmo ${ }^{1}$.

O Vaticano, por sua vez, tendo status de observador da ONU, esteve na RIO+20 e pressionou o governo brasileiro para que não se aprovasse o texto original no tocante aos "direitos reprodutivos" das mulheres.

\footnotetext{
${ }^{1}$ Adaptado do texto de Isabel Fleck e Eduardo Gerarque. Folha de São Paulo, 20/06/2012.
} 
O teor do discurso do presidente iraniano e a presença do Vaticano na Rio +20 suscita-nos a seguinte indagação: No mundo altamente secularizado, haveria lugar para as religiões no atual cenário das Relações Internacionais (RI) $?^{2}$ Por que refletir acerca do tema Religiões no Brasil e Relações Internacionais no século XXI?

Talvez, para outros observadores o discurso do presidente de um país islâmico, como o Irã, não poderia ser diferente. Afinal, poder-se-ia objetar, a religião islâmica fundamenta o próprio Estado iraniano. Por outro lado, se poderia pensar que a pressão do Vaticano sobre o Brasil, nada mais seria que uma manifestação simbólica da mais antiga Instituição transnacional da história.

Contudo, um outro evento religioso internacional nos chama a atenção. A Jornada Mundial da Juventude (JMJ) no Rio de Janeiro em 2013. A JMJ foi iniciada pelo Papa João Paulo II em 1985 na Itália. Daí em diante a JMJ tem acontecido em vários países, reunindo milhões de católicos, especialmente jovens.

Por sua vez, pastores evangélicos criaram a Marcha para Jesus em Londres em 1987, cujo movimento ganhou adeptos em alguns países da Europa. Esse movimento chegou ao Brasil em 1993, quando a Igreja Renascer em Cristo organizou em São Paulo a primeira Marcha para Jesus. A partir daí, esse evento religioso se expandiu para inúmeras cidades e estados brasileiros, mobilizando populações fiéis de diversas igrejas evangélicas no território brasileiro.

Qual seria a importância desses movimentos de populações religiosas no Estado nacional e nas relações interestatais? A população se constitui como uma categoria fundamental no estudo da geografia política renovada. É através da população que todo o restante das coisas econômicas, técnicas, sociais, culturais e políticas perpassam e adquirem múltiplos significados. É ela que exerce a cidadania e o poder de consumidor, trabalhador, eleitor, fiel, etc. É por causa da população que todas as coisas na humanidade podem ser ou não coerentes ou paradoxais. (RAFFESTIN, 1993).

\footnotetext{
${ }^{2}$ Ao longo do texto utilizaremos as letras em maiúscula RI para indicar o termo Relações Internacionais enquanto área de estudo.
} 
Fundamentado em vários pensadores como, por exemplo, nas ideias de Morin para quem a noosfera ou esfera das coisas do espírito estão presentes desde os albores da vida do Homo Complexus (MORIN, 2005); na visão de Weber para quem a ação religiosa é de natureza econômica e na importância da religião no caráter nacional (WEBER, 1984, 2004); nas ideias de Eliade para quem até mesmo o homem moderno sem religião traz a religiosidade nas profundezas de seu inconsciente (ELIADE, 2001); bem como na visão de Breton que sugere a retomada do estudo da geografia das civilizações para o século XXI (BRETON, 1990); além do recente estudo em geografia humana que defende a existência de geopolítica das igrejas e anarquia religiosa da população sem religião no Brasil (SANTOS, 2011), e considerando que o sistema político internacional abriga vários subsistemas como, por exemplo, a ordem ambiental internacional (RIBEIRO, 2001), apresenta-se a seguir uma questão central que a consideramos motivadora nesta reflexão, a saber:

Numa nova visão diferente da tese do "choque de civilizações" (HUNTINGTON, 1997), qual seria o papel ou a contribuição das religiosidades no Brasil para a paz mundial e para a construção de uma nova ordem espiritual nas relações Internacionais?

A seguir, faremos sucinta abordagem sobre a crise de paradigmas nos estudo de RI e indicaremos possibilidades de reflexão sobre as religiões nesse cenário de crise a partir da realidade brasileira.

\section{Relações Internacionais, crise de paradigmas e novos olhares para as religiões}

Vários pesquisadores demonstram com maestria a importância do estudo dos pensadores clássicos das RI para a compreensão do sistema político internacional. Dentre estes pensadores destacam-se Maquiavel, Morgenthau, Raymond Aron, Hedley Bull, James Rosenau, Robert W. Cox, e outros. No entanto, fica claro, segundo os especialistas nesses pensadores, que os paradigmas das RI são heterogêneos, cabendo inclusive visões que, em certa medida, se antagonizam e também visões que se aproximam e/ou se complementam entre os clássicos das RI. (MEDEIROS, et al. 2010). 
Além da diversidade dos paradigmas das RI, constata-se também complexidade ao se estudar as RI numa perspectiva histórica - desde as revoluções do século XVIII, (francesa, napoleônica), passando pelas revoluções do século XIX, (industrial, os nacionalismos e o surgimento das ideias comunistas), o curto século XX (as duas grandes guerras 1914-18 e 1939-45, a bipolaridade, o inicio e o fim da Guerra Fria e até a implosão do bloco comunista) - temas esses analisados por vários especialistas em História das RI. (SARAIVA, 2008).

A complexidade das RI, sobretudo após o fim da Guerra Fria que provocou profundas mudanças no sistema político internacional surpreendendo até mesmo internacionalistas, revela também que os paradigmas dominantes nas análises das RI entraram em crise.

No entanto, essa crise de paradigmas nas RI possibilita novas abordagens como, por exemplo, as análises do discurso religioso da "direita cristã" norte-americana com transbordamento para a política externa dos Estados Unidos (MATEO, 2011), bem como outro estudo que analisa a política externa dos Estados Unidos fortalecida pela "(re)produção da ideologia puritana e o discurso de americanidade" em sintonia com a "religião civil como identidade nacional". (RESENDE, 2009).

No contexto de crise dos paradigmas das RI, vários analistas propuseram novas ideias como tentativas de explicar e até mesmo intervir na nova ordem mundial no sistema político internacional em gestação. Nesse sentido, analistas internacionais como Huntington (1994, 1997), Fukuyama (1992; 2006), Kennedy (1988, 1993) Wallerstein (1991), Minc (1994), Ramonet (1998), entre outros, são exemplos de visões que sugerem, ao nosso entendimento, que o estudo das RI na história contemporânea comportam múltiplos olhares.

Essas múltiplas visões ou ideias produzidas por analistas norte-americanos, ingleses e franceses acerca do sistema político internacional, além de explicar o mundo, seriam também ideias que ajudam a redefini-lo. Por exemplo, quando Huntington (1997) propõe a tese de "choque de civilizações" ou quando Fukuyama (1992) defende "o fim da história" com a defesa da democracia liberal, essas ideias 
seriam também discursos que promovem intervenção no mundo em defesa de seu pais os Estados Unidos (VESENTINI, 2000).

Esses múltiplos olhares sobre as RI no mundo atual, possibilita também pensar que o sistema político internacional abriga vários subsistemas como, por exemplo, o subsistema da "Ordem Ambiental Internacional", em construção, segundo a visão do geógrafo Wagner Costa (RIBEIRO, 2001).

Além disso, os múltiplos olhares e estudos de RI permitem entender que as relações no sistema político internacional não estão restritas ao espaço territorial do Estado-Nação, "são relação mais amplas e complexas, não raro envolvendo vasto espectro de atores e, quase sempre, abrangendo diferentes vertentes da sociedade", como sugerem vários cientistas políticos (MEDEIROS et al, 2010, p.17).

Nesse mesmo sentido, referindo-se ao cenário político internacional após a Guerra Fria, o geógrafo J.W.Vesentini (2000) defende que as relações de poder não são apenas exercidas pelos Estados nacionais. Novos atores ou sujeitos participam e interferem nas relações internacionais, desde as civilizações ou grandes culturas até as $0 \mathrm{NG}^{\prime}$ 's, passando pelas empresas multi ou transnacionais, organizações internacionais (ONU, OMC, FMI, e outras), etc. No cenário das "novas geopolíticas", segundo Vesentini, "novos campos de lutas são agora importantes nas relações de poder no espaço mundial, como a questão ambiental, as lutas pelos direitos das mulheres, das minorias étnico-nacionais, de grupos com diferentes orientações sexuais, etc". (VESENTINI, 2000, p.11).

Entre vários estudiosos da história das relações internacionais contemporâneas, o cenário mundial neste século XXI sugere diferentes paradigmas de conformação dos poderes no sistema político internacional. Dentre esses estudiosos, a visão de José Flávio S. Saraiva sugere que "o sistema político internacional apresenta alto grau de anarquia transicional" (SARAIVA, 2008, p. 346).

Nessa linha de raciocínio, que considera a anarquia transicional como característica do sistema internacional, porém, analisando a realidade brasileira, foi desenvolvida a tese de doutorado em Geografia Humana, na Universidade de São Paulo - USP, intitulada "Geopolítica das Igrejas e Anarquia Religiosa no Brasil: Por uma Geoética do apoio mútuo". (SANTOS, 2011). Essa tese tem 
como foco central, de um lado, a preocupação científica acerca da rivalidade de poderes e influências das igrejas nos territórios e, de outro, a análise do processo de mutação das religiosidades da população brasileira no tocante à autonomia religiosa da população sem religião no território brasileiro. Em síntese, a tese demonstra que há geopolíticas, rivalidades inclusive com intolerância entre, principalmente, a Igreja Católica e as Igrejas Evangélicas (de modo geral). Entretanto, a autonomia religiosa da população sem religião sinaliza para a tolerância aberta, isto é, tolerância sem fronteira ou distinção de crença e cooperação na busca de solução pacífica dos conflitos no contexto da diversidade religiosa.

Analisando a história das relações internacionais contemporâneas, um historiador internacionalista sugere novos temas de pesquisa para o século XXI, como a diversidade cultural, os processos sociais de identidade e a "hipoteca das religiões sobre as mentalidades" (MARTINS, 2008, p.IX).

Nesse contexto, temos a considerar os três pressupostos a seguir:

O primeiro pressuposto a se considerar a respeito do tema desta reflexão diz respeito, de um lado, a laicidade do Estado brasileiro que garante o direito constitucional de liberdade religiosa e, de outro lado, a não interferência do Estado sobre as religiões. Nesse sentido, poderíamos considerar que existe anarquia das religiões, isto é, ausência de governo do Estado sobre as religiões.

O segundo pressuposto tem a ver com o pluralismo religioso que se expressa nas mais diversas formas ou sentidos de crença entre o povo brasileiro. Esse universo religioso se constitui das populações adeptas aos cultos afro-brasileiros (os candomblés e umbandas), populações católicas, as populações protestantes (dos mais diversos sentidos e denominações), populações espíritas, populações adeptas às religiões orientais (budismo e hinduísmo), populações das comunidades judaicas e islâmicas. Além desse universo, existe também mais de 15 milhões de pessoas religiosas sem religião - ex-católicos, ex-evangélicos, etc. Ao fenômeno nacional de população sem religião chamamos de anarquia religiosa. (SANTOS, 2011). 
E o terceiro pressuposto desta reflexão se relaciona ao cenário de geopolítica das igrejas, especialmente a Igreja Católica e as Igrejas Evangélicas, que exercem influências políticas sobre as populações religiosas adeptas desses dois segmentos no território brasileiro. As geopolíticas das igrejas possibilitam ações estratégicas para manter e expandir o "capital religioso" das respectivas igrejas. Por exemplo, a Jornada Mundial da Juventude (JMJ) no Brasil (Rio de Janeiro) em 2013, evento iniciado pelo Papa João Paulo II em 1985 na Itália; os movimentos de populações evangélicas nas “Marchas para Jesus", iniciado em 1993 e em expansão pelo território brasileiro, bem como a presença de parlamentares evangélicos no Congresso Nacional, além da influência política das igrejas católicas e evangélicas através dos meios de comunicação e os fluxos e ações de milhares de missionários cristãos em diversos países do exterior. Essas ações, entre outras, são estratégias das geopoliticas das igrejas. (SANTOS, 2011).

Nesse sentido, considerando as ideias explicitadas até aqui (crise de paradigmas das RI, novo olhares para as religiões, etc) no cenário das RI no século XXI, colocaremos a seguir três afirmações como ponto de vista para reflexão e debate:

a) Os atores religiosos no cenário nacional brasileiro influenciam e são influenciados pelo sistema político-religioso internacional.

b) A política do Governo brasileiro em relação às religiões no cenário nacional pode influenciar e ser influenciada pelas relações internacionais.

c) O patrimônio espiritual e a mutação das religiosidades brasileiras contribuem para a paz e tolerância religiosa aberta, isto é, sem fronteira, sem distinção de crença, bem como para a construção de uma nova ordem espiritual, como parte das civilizações no espaço mundial, no cenário das relações internacionais neste século XXI.

\section{Religião e Relações Internacionais}

Ao olhar para o passado da história das relações internacionais no Ocidente, constata-se que a regulação dos conflitos políticos, econômicos e religiosos nos territórios era exercida 
internacionalmente pelo poder papal. Esse sistema político-religioso foi radicalmente abalado com a Reforma Protestante (1517), seguido por inúmeras guerras religiosas, entre católicos e protestantes como, por exemplo, a Guerra dos Trinta Anos (1618-1648). Fora do controle do poder papal, esse cenário de guerras religiosas teve um fim somente com o Tratado de Paz de Westfália (1648), no qual se estabeleceu o reconhecimento da soberania dos Estados em processo de formação (ROMANO, 2008).

Pode-se considerar que desde o Tratado de Paz de Westfália as RI se pautaram, em certa medida, na visão de racionalidade que fundamenta o Estado moderno, colocando a religião cada vez mais num plano secundário no sistema político internacional.

Contudo, indaga-se, passados quase quatro séculos desde Westfália até hoje, haveria lugar para as religiões na história das relações internacionais no século XXI?

Para um cientista político norte-americano, ex-assessor estrategista na época da Guerra do Vietnã, no governo do presidente Richard Nixon (1969 a 1974), a resposta é sim. Segundo Huntington, "a separação westfaliana da religião e da política internacional, produto idiossincrático da civilização ocidental, está chegando ao fim, e a religião tem probabilidade cada vez maior de se imiscuir nos assuntos internacionais". (HUNTINGTON, 1997, p.62).

No entanto, em que medida e como atores internacionais poderiam imiscuir-se, por exemplo, na política nacional brasileira através da religião?

Essa é uma questão que merece ser investigada. Ressalta-se, porém, um fato recente como evidência: nas eleições democráticas de 2010 para presidente da República Federativa do Brasil, o segundo turno das eleições foi invadido pela religião, tanto a Igreja Católica como algumas Igrejas Evangélicas. Por exemplo, até mesmo o Papa Bento XVI recomendou aos Bispos brasileiros que orientassem aos fiéis 
politicamente para não votar em candidato que entende o aborto como problema de saúde pública e não como assunto religioso ${ }^{3}$.

Afinal, após longo processo de secularização, estaríamos como sugeriu Alain Minc (1994), voltando à nova Idade Média? A história seria cíclica?

Dentre as profundas transformações sociais e políticas entre os séculos XVIII e XIX que marcaram a Era das Revoluções (1789-1848), o historiador Eric Hobsbawm (1977) destaca, de um lado, a revolução da ideologia religiosa e, de outro, a revolução da ideologia secular.

Hobsbawm (1977) demonstra que até antes de 1848, os termos em que todos os homens - com raras exceções - pensavam o mundo eram segundo a visão da religião tradicional. Contudo, a ideologia secular transformou radicalmente a vida social naquele contexto.

Ao passo dos avanços do secularismo no processo revolucionário do século XIX, nas palavras do historiador britânico, as "seitas protestantes" também cresceram significativamente, uma vez que para a massa da população, o retorno à religião era um método de luta contra a sociedade cada vez mais fria, desumana e tirânica do liberalismo da classe média (HOBSBAWM, 1977).

Contudo, o secularismo avançou em toda a sociedade, tendo sido aprofundado no século XX. Haveria, porém, lugar para as religiões na História das Relações Internacionais no século XXI?

Segundo Hobsbwam, as forças históricas que moldaram o século XX continuam a operar neste século XXI. E dentre essas forças históricas destaca-se a Revolução Islâmica no Irã em 1979, cujo fato

\footnotetext{
${ }^{3}$ FOLHA DE SÃO PAULO, 28/10/2010. Vale lembrar que o segundo turno das eleições aconteceu no dia seguinte ao pronunciamento do papa. $\mathrm{O}$ assunto foi amplamente inserido na mídia durante todo o segundo turno das eleições. Por exemplo, de um lado, a revista VEJA publicou matéria de capa com a foto da candidata Dilma Rousseff (PT), destacando o assunto aborto (edição 2187 - 13/10/2010) e, de outro lado, a revista ISTOÉ publicou reportagem com a foto do candidato a presidente José Serra ( PSDB) beijando o "Crucifixo", na capa da revista, com o título "Santos e Santinhos de uma guerra suja". (ISTOÉ 2137 - 22/10/2012).
} 
histórico surpreendeu até mesmo o serviço secreto (CIA) do governo norte-americano (MATEO, 2011).

Em que medida o cenário de governança sem governo (ROSENAU, 2000) afetaria não apenas as pessoas religiosas, mas aos cidadãos como atores neste século XXI? A respeito da cidadania sob a poliarquia, Rosenau entende que a crise de autoridade nos pós-Guerra Fria, ou ordem mundial de governança sem governo, influencia na esfera dos cidadãos e estes, como atores, influenciam na política interna dos Estados que, por sua vez, redefinem seu papel nas relações internacionais. (ROSENAU, 2000, pp.363-392).

Nos estudos das RI o tema da religião não foi devidamente analisado. Afinal, desde a Paz de Westfália, com a distinção dos poderes espirituais e temporais, em tese, a religião não deveria se envolver nas coisas da vida pública.

No entanto, há que se considerar o papel desempenhado pelo Vaticano no decorrer da Guerra Fria, especialmente sua influência política para a derrocada do regime soviético no Leste Europeu e também no combate à expansão das ideias marxista nas Comunidades Eclesiais de Base (CEB's), inspiradas pela Teologia da Libertação na América Latina. Nesse contexto, a geopolítica do Vaticano esteve em aliança com a "direita cristã" norte-americana, especialmente a partir do governo do presidente Ronald Reagan na década de 1980 (COLONNA-CESARI, 1993).

Além desse papel de destaque do Vaticano no processo de derrocada do "socialismo real", há que se considerar na história das RI os encontros e desencontros entre a Santa Sé e a República Popular da China, de 1949 a 2005, analisado com lucidez pela historiadora Anna Carletti na obra "Diplomacia e Religião" (CARLETTI, 2008).

Com o fim do período histórico da Guerra Fria, porém, um analista norte-americano das relações internacionais considerou que a nova ordem mundial que se desenhava a partir do inicio da década de 1990, teria forte influência cultural e religiosa, levando-o até mesmo a afirmar que "ao lidar com uma 
crise de identidade, o que conta para as pessoas é sangue e crença, fé e família.” (HUNTINGTON, 1997. p.154).

Temos a considerar que o cenário religioso no Brasil tem relação com o sistema político internacional, de um lado, a influência da geopolítica do Vaticano (COLONNA-CESARI, 1993) e, de outro lado, o pensamento político norte-americano que defende a expansão do protestantismo - especialmente o pentecostalismo - no território brasileiro e no mundo atual. (BERGER \& HUNTINGTON, 2004; BERGER, 2001).

Contudo, poder-se-ia objetar: na sociedade técnico-científica atual, cujo avanço da ciência se expande e o acesso ao conhecimento se democratiza não estaríamos chegando à morte, ao fim, à extinção da religião?

Na visão de Sigmund Freud (1856-1939), considerado como o pai da psicanálise, a religião nada mais seria que uma "ilusão necessária", uma manifestação da frustração da infância em relação à ausência paterna, que na vida adulta o homem expressaria através do apego à religião, ao mito de um "pai mais poderoso" para amenizar ou escamotear o sentimento de desamparo frente às vicissitudes da vida. Na medida em o homem adquirisse conhecimento científico se afastaria da religião. Nesse sentido, segundo o pensamento freudiano na obra "O Futuro de uma Ilusão", a religião estaria destinada ao fim com a crescente autonomia do ser humano. (FREUD, 1997).

Entretanto, mesmo com o avanço da ciência e a democratização do acesso ao conhecimento, bem como o forte impacto da globalização, a religião continua influenciando a vida das pessoas no cotidiano e até mesmo influenciando na vida pública nos Estados nacionais e nas relações internacionais. Como defende Peter Byer, "a resistência a, ou, talvez, melhor, a digestão da globalização em diversas partes de mundo contemporâneo deu origem a movimentos informados pela opção religiosa conservadora." (BYER, 1994). 
Nesse sentido, destaca-se que para o sociólogo francês Émile Durkheim (1858-1917), a origem da religião é essencialmente humana, social; por esta razão ela não estaria destinada a desaparecer da sociedade, ao contrário, a religião permaneceria no mundo, porém, seria chamada a se transformar, a se adaptar à realidade. Além disso, segundo Durkheim, não existe religião falsa, todas as religiões são verdadeira à sua maneira. (DURKHEIM, 2004).

Além da concepção durkheimiana, merece ser destacada a visão de um historiador das religiões. Mircea Eliade defende que mesmo o homem moderno a-religioso, traz a herança do homo religiosus nas profundezas de seu inconsciente. Nesse sentido, a estrutura mitológica estaria presente até mesmo no comunismo e em seu sentido escatológico proposto por Karl Marx. (ELIADE, 2001)

Segundo Eliade (2001), ao propor o comunismo e o papel do proletariado como redentor dos sofrimentos do mundo, Marx retoma e prolonga um dos grandes mitos escatológicos do mundo asiático mediterrâneo: o justo, o eleito, o ungido, o mensageiro, nos dias atuais na figura do proletariado. Seria ainda o enriquecimento do mito da luta final entre o Bem e o Mal, ou entre o Cristo e o Anticristo, sendo a vitória do primeiro simbolizado pela vitória do proletariado com o fim das classes sociais, idealizado por Marx.

Nesse sentido, entendendo que a transcendência, o mito, a religiosidade está presente no inconsciente humano, temos ainda a visão de Edgar Morin que propõe a teoria da complexidade e defende que a noosfera - esfera das coisas do espírito - é intrínseca à estrutura bio-físico-psíquica do Homo Complexus (MORIN, 2005).

Nas palavras de Morin:

Devemos estar bem conscientes de que, desde o alvorecer da humanidade, encontra-se a noção de noosfera a esfera das coisas do espírito -, com o surgimento dos mitos, dos deuses, e o extraordinário levante dos seres espirituais impulsionou e arrastou o Homo sapiens a delírios, massacres, crueldades, adorações, êxtases e sublimidades desconhecidas no mundo animal. (...) Os humanos possuídos são capazes de morrer ou matar por um deus, por uma ideia. (MORIN, 2005, pp.28-29). 
Assim sendo, se a noosfera, isto é, a "esfera das coisas do espírito" (MORIN, 2005), é parte da complexidade humana, como relacioná-la à esfera política do Estado e às relações internacionais?

Nos estudos das Relações Internacionais durante décadas a religião foi marginalizada. Somente a partir da década de 1980 e 1990, a religião começou a surgir nos estudos de Relações Internacionais. (MATEO, 2011; RESENDE, 2009).

Contudo, pelo menos desde o inicio do século XX o sociólogo alemão Max Weber (1864-1920) havia enfatizado a importância do estudo da religião para a formação da cultura e para a constituição da política no Estado nacional. No entanto, segundo Weber "o homem moderno, mesmo com a melhor das vontades, costuma ser incapaz de atribuir às ideias religiosas a importância que merecem em relação à cultura e ao caráter nacional." (WEBER, 2004, p.136).

Ressalta-se que, segundo Weber, a ação religiosa é uma ação racional, ou pelo menos se orienta pelas regras da experiência, e está voltada para este mundo (não para o além), sendo que seus fins são de natureza econômica. (WEBER, 1984). Na obra "A Ética Protestante e o Espírito do Capitalismo", Weber demonstra a importância fundamental de certo protestantismo - o calvinismo - na formação do capitalismo, uma vez que a doutrina calvinista da predestinação interpreta o êxito material como garantia da graça divina. (WEBER, 2004).

Nas décadas de 1950/60 sociólogos da religião elaboraram a teoria da secularização, cuja ideia central era que a modernidade (progresso da ciência e da tecnologia) eliminaria a religião da sociedade, uma vez que a separação entre Estado e Igreja reduziu drasticamente a influência da religião na vida pública. Nesse sentido, a civilização ocidental que já estava diante do desencantamento do mundo passou a ser cada vez mais secularizada, laica, profana, não-religiosa (PIERUCCI, 2003).

Contudo, passadas algumas décadas, Peter Berger, sociólogo norte-americano da Universidade de Boston, um dos idealizadores da teoria da secularização, publicou, em 1999, a obra "A Dessecularização do Mundo" cuja ideia central é que a teoria da secularização era essencialmente falsa 
ou equivocada. Ou seja, Berger refuta a teoria da secularização com uma nova ideia, a teoria da dessecularização. Agora, segundo ele, o mundo é essencialmente religioso, "e tão ferozmente religioso quanto antes, e até mais em certos lugares". (BERGER, 2001, p.10).

No contexto do pós-Guerra Fria a revalorização das tradições culturais e religiosas, bem como os conflitos étnico-religiosos ganhou destaque na geografia política mundial. Por exemplo, o atentado terrorista às torres do World Trade Center, nos Estados Unidos, no 11 de setembro de 2011, cuja autoria foi assumida pela $A l$ Qaeda, organização fundamentalista islâmica liderada pelo saudita Osama Bin Laden -, revela a importância política das religiões no cenário mundial e impulsiona a necessidade de leitura e estudo das religiões neste século XXI.

Sob o comando do presidente George Walker Bush (do partido republicano e evangélico da Igreja Metodista Nova), as forças armadas norte-americanas bombardearam o Afeganistão e invadiram o Iraque, ambos os países islâmicos, como pretensa resposta ao terrorismo fundamentalista. Na eleição presidencial dos Estados Unidos, em novembro de 2004, a sociedade norte-americana viveu uma forte onda de conservadorismo religioso que favoreceu decisivamente a reeleição do presidente Bush. (FUKUYAMA, 2006).

Aliás, "estudiosos da matéria reconhecem que a religião é parte da política americana pelo menos desde que George Washington colocou a mão direita sobre a Bíblia para prestar juramento como primeiro presidente do país." (FERREIRA, 2004, p.65) ${ }^{4}$.

É curioso observar que desde 1989 surgiu nos Estados Unidos, entre os evangélicos, a ideia da chamada "Janela 10-40", isto é, espaço geográfico localizado entre os paralelos $10^{\circ}$ e $40^{\circ}$ ao norte da linha do Equador, abrangendo todo o norte do continente africano (África Islâmica ou Branca), o Oriente Médio, a Índia, até o extremo leste da Ásia. (veja a figura cartograma a seguir):

\footnotetext{
${ }^{4}$ FERREIRA, Argemiro. O Império contra-ataca. - as guerras de George W. Bush antes e depois do 11 de setembro. São Paulo Paz e Terra, 2004. A obra trata-se de interessante abordagem revelando o papel estratégico da direita cristã e dos conspiradores fundamentalistas desde a era Ronald Reagan até George W. Bush.
} 


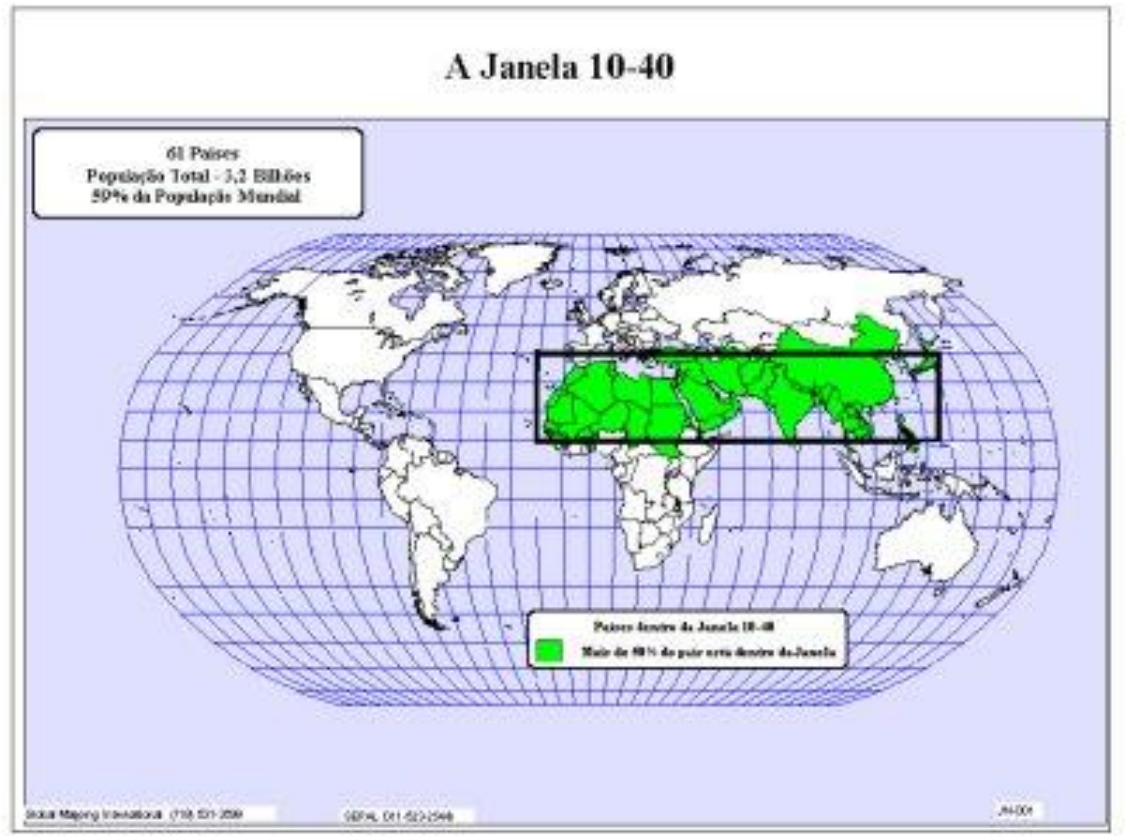

Figura 1. Cartograma de represntação da Janela 10-40

Fonte: www.montesiao.pro.br (acessado em 17/06/2012).

Na região da "Janela 10-40" as religiões predominantes são o islamismo, o hinduísmo e o budismo. Segundo as igrejas evangélicas de missões, essa região é pobre e vive em conflitos porque ainda não é uma região cristã, por isso deve ser conquistada e cristianizada para que se torne uma região rica e abençoada. (SANTOS, 2011).

Nesse sentido, nota-se que no século XXI a religião começa a atrair o interesse de estudiosos das Relações Internacionais, uma vez que a religião influencia a política externa de uma das maiores potência mundial da atualidade, a saber, os Estados Unidos da América.

Estudos recentes na área de RI estão apontando a importância da religião na política externa dos EUA como, por exemplo, a tese de doutorado da cientista política Érica Simone Resende que analisa a (re)produção da ideologia puritana e o discurso de americanidade da religião civil nos Estados Unidos, após o episódio do 11 de setembro (RESENDE, 2009).

Outro estudo acadêmico recente "Deus abençoe a América: religião, política e Relações Internacionais dos Estados Unidos", de Luiza Rodrigues Mateo, analisa a influência da religião desde a fundação dos 
Estados Unidos até o final do século XX, com o recente movimento civil organizado pela "direita religiosa" influenciando o Congresso Nacional e a política externa dos Estados Unidos (MATEO, 2011).

Por fim, vale ressaltar que se, de um lado, a globalização desagrega e provoca crise de identidade nas pessoas, por outro lado, o avanço nos meios de transportes e comunicação facilita o contato com o outro que é estranho, diferente de nós. A condição pós-moderna neste século XXI, fenômeno que o geógrafo norte-americano David Harvey (1994) chamou de "compressão do espaço-tempo" diminui as distancias entre os povos, como representa a figura a seguir:

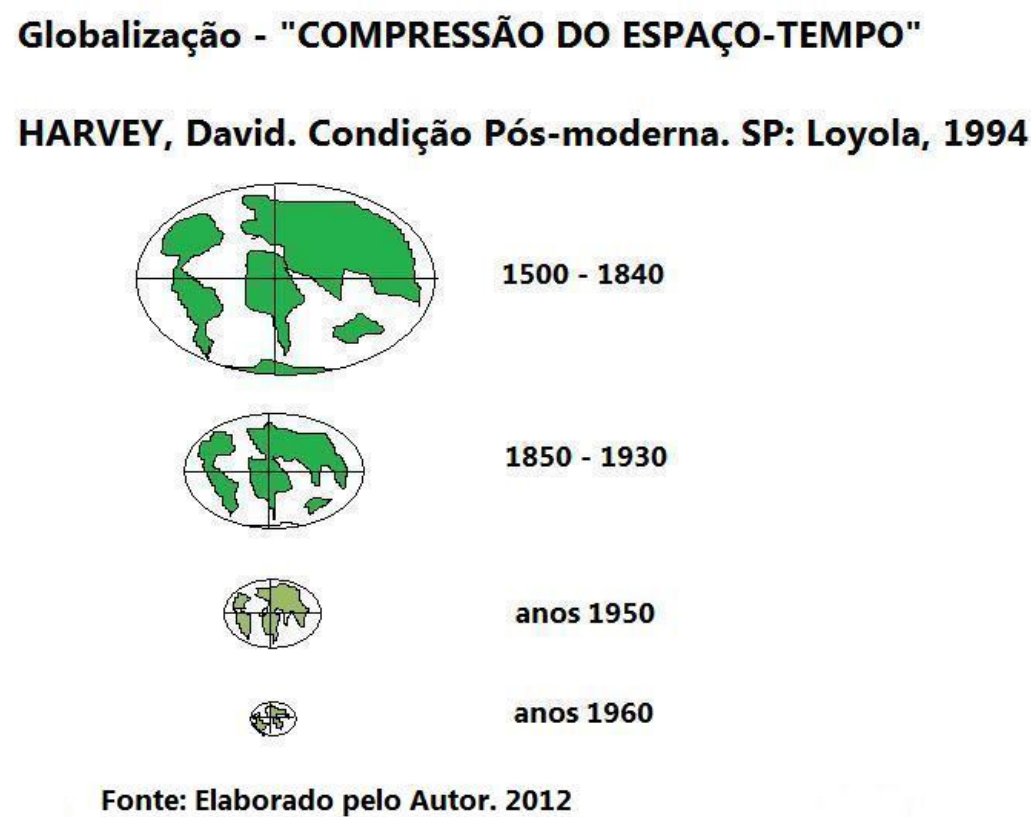

Figura 2. Globalização: compressão do espaço-tempo. Fonte: Harvey (1994).

A globalização não só trouxe impactos na economia internacional, como também no campo religioso mundial produziu efeitos inesperados desafiando até mesmo especialistas em congressos internacionais a repensar seus paradigmas e conceitos na área de antropologia e de sociologia da religião. (ORO, 1999). 
Contudo, a meu ver, a globalização possibilita ao ser humano pensar e repensar seus valores, buscando novos caminhos da religiosidade que leve em conta talvez o desenvolvimento da autonomia da fé com diálogo transreligioso e tolerância aberta, isto é tolerância sem fronteira, sem distinção de crença na busca de soluções pacíficas dos conflitos na perspectiva da construção de uma nova ordem espiritual planetária.

Refletindo sobre a "grande mutação contemporânea" e o tempo histórico atual, Milton Santos (2000) finaliza sua obra com esperança:

\footnotetext{
Agora que estamos descobrindo o sentido de nossa presença no planeta, pode-se dizer que uma história universal verdadeiramente humana está, finalmente, começando. (...) Muito falamos hoje nos progressos e nas promessas da engenharia genética, que conduziriam a uma mutação do homem biológico, algo que ainda é do domínio da história da ciência e da técnica. Pouco, no entanto, se fala das condições, também hoje presentes, que podem assegurar uma mutação filosófica do homem, capaz de atribuir um novo sentido à existência de cada pessoa e, também, do planeta. ( SANTOS, 2000, p. 174).
}

Por sua vez, valorizando o estudo da geografia das civilizações para o século XXI, inspirado nas ideias do historiador Arnold Toynbee, bem como na experiência cultural dos anos de 1968, Roland Breton conclui:

A dialética entre imanência e transcendência está na base da gênese das civilizações. Isto é o que deveriam ter em mente todos aqueles que sonham ou atuam em prol de uma nova ordem mundial, do futuro de nossas civilizações, particulares... ou planetárias, e deverão encontrar, mesmo para o século XXI, mitos fundadores e perspectivas escatológicas. (BRETON, 1990, p.124).

É nessa perspectiva que se insere esta reflexão, cuja questão central motivadora merece ser colocada novamente:

Numa nova visão diferente da tese do "choque de civilizações" (HUNTINGTON, 1997), qual seria o papel ou a contribuição das religiosidades no Brasil para a paz mundial e para a construção de uma nova ordem espiritual na história das relações internacionais?

Assim sendo, parece-nos pertinente refletir sobre o tema "Religiões no Brasil e Relações Internacionais no século XXI". Afinal, no Brasil se encontram populações adeptas de praticamente 
todas as grandes religiões mundiais convivendo no mesmo território nacional, com relativa tolerância e diálogo.

Mais que tolerância religiosa (SANTOS, 2002), acreditamos hoje que é urgente pensar na construção do diálogo trans-religioso. Esse diálogo trans-religioso está na esfera da autonomia da fé, sem governo, porém, com apoio mutuo entre as pessoas acontece de baixo para cima e em todas as direções com respeito ao outro, ao diferente, entre pessoas religiosas das diversas crenças e também diálogo com aqueles que se declaram sem religião, porém, possuem espiritualidade. Afinal, as religiosidades dos brasileiros estão em mutação, talvez, sinalizando para a invenção brasileira de uma nova ordem espiritual. (SANTOS, 2013).

Ao contrário da tese de choque de civilizações, caberia pensarmos a respeito do papel do Brasil e das religiosidades dos brasileiros no cenário das relações internacionais neste século XXI. Pensarmos na construção do diálogo entre as religiosidades sobre novas epistemologias e ontologias que possibilitem, por exemplo, olhar para o mundo islâmico, como sugere o historiador Peter Demant, não a partir da visão etnocêntrica do Ocidente, mas olhar o islamismo em sua riqueza que carece e permite também o diálogo com o outro, diálogo entre as fés e civilizações (DEMANT, 2008).

\section{CONSIDERAÇÕES FINAIS}

Neste artigo procurou-se introduzir esse tema para reflexão, debate e até como tema para futuras analises do cenário de ausência de governo do Estado Democrático de Direito sobre as religiões no território brasileiro e refletir acerca da contribuição do cenário das religiosidades no Brasil para com as Relações Internacionais numa nova ordem mundial em gestação neste século XXI.

Paul Kennedy, historiador inglês, analisou a história da ascensão e queda das grandes potências, de 1500 ao ano 2000. Nessa análise as potências romana, turco-otomana, inglesa e finalmente norteamericana tiveram grande destaque no espaço político internacional (KENNEDY, 1988). 
Outro historiador inglês, Walter Laqueur, demonstra a crise e decadência da Europa na obra "Os últimos dias da Europa - Epitáfio para um velho continente”. (LAQUEUR, 2007).

Por sua vez, o geógrafo brasileiro J.William Vesentini defende as "Novas Geopolíticas" demonstrando que além dos Estados nacionais novos atores participam e influenciam nas relações internacionais. Para esse geógrafo as ideias não somente explicam o mundo como também ajudam a redefini-lo. (VESENTINI, 2000).

Na perspectiva de atores não governamentais participando e interferindo nas relações internacionais, a mutação das religiosidades dos brasileiros, inclusive o processo de autonomia da fé a partir do crescimento da população sem religião, sinaliza para a tolerância aberta, isto é, tolerância sem fronteira, sem distinção de crença. Portanto, ampliação da tolerância religiosa (não somente entre alguns segmentos cristãos como, por exemplo, católicos e protestantes históricos) e especialmente com diálogo trans-religioso no sentido da reflexão para o enfrentamento dos problemas socioambientais, enfim tolerância espiritual no sentido do entendimento, compreensão e busca de soluções para a crise ambiental a partir de diferentes sentidos de crença. Evidências empíricas, nesse sentido, foram demonstradas sinalizando uma geoética nas relações internacionais. (SANTOS, 2012).

Nesse contexto, tratou-se aqui apenas de uma reflexão livre apoiada nas referências indicadas, mas, sobretudo a partir de nosso próprio olhar geográfico para o papel do Brasil enquanto nação com singular patrimônio espiritual, cujas religiosidades da população brasileira estão em mutação, porém, num Estado-nação em crescimento econômico e em destaque político no cenário internacional.

Neste novo cenário, o Brasil deixou de ser devedor e passou a ser provedor no FMI. Mas não apenas isso. No cenário de crise mundial, o Brasil contribui para o equilíbrio internacional com a exportação não somente de gêneros agrícolas e produtos materiais, como também com a troca de bens espirituais.

Quiçá esta sucinta contribuição geográfica, fundamentada na geoética do apoio mútuo, possa somar-se a outros olhares para a construção de novos caminhos nas relações internacionais. Afinal, o Brasil 
chegou neste futuro presente carregando do passado a herança religiosa de praticamente todos os povos e civilizações. Esperamos que esse patrimônio espiritual fomente, a partir deste século, pontos de encontros e diálogos entre as religiosidades internacionais para a invenção de um mundo novo...

\section{REFERÊNCIAS}

BEYER, Peter F. “A privatização e a influência pública da religião na sociedade global”. IN: FEATHERSTONE, Mike (Org.). Cultural Global: nacionalismo, globalização e modernidade. Petrópolis: Vozes, 1994.

BERGER, Peter. Dessecularização do mundo: uma visão global. Rio de Janeiro: Religião e Sociedade, vol.21, nº 1, 2001.

BERGER, Peter; HUNTINGTON, Samuel P. (Org.). Muitas Globalizações: Diversidade Cultural no mundo contemporâneo. Rio de Janeiro: Record, 2004.

CARLETTI, Anna. Diplomacia e Religião: encontros e desencontros nas relações entre a Santa Sé e República Popular da China de 1949 a 2005. Brasília: FUNAG, 2008.

COLONNA-CESARI, C. Urbi Et Orbi - A Geopolítica do Vaticano. Lisboa-Portugal: Caminho, 1993.

DEMANT, Peter. O Mundo Muçulmano. $2^{\text {a }}$ ed. São Paulo: Contexto, 2008.

DURKHEIM, Émile. As Formas Elementares de vida Religiosa. São Paulo: Martins Fontes, 2004.

ELIADE, Mircea. O Sagrado e o Profano. São Paulo: Martin Fontes, 2001.

FERREIRA, Argemiro. O Império contra-ataca. São Paulo: Paz e Terra, 2004.

FUKUYAMA, Francis. O dilema americano. Rio de Janeiro: Rocco, 2006.

FUKUYAMA, Francis. O fim da História e o último Homem. Rio de Janeiro: Rocco, 1992.

HARVEY, David. Espaços de Esperança. São Paulo: Loyola, 2004.

HARVEY, David. Condição Pós-moderna. São Paulo: Loyola, 1994.

HOBSBAWM, Eric. Era dos Extremos: o breve século XX 1914-1991. São Paulo: Cia. das Letras, 1995.

HOBSBAWM, Eric. A Era das Revoluções (1789-1848). São Paulo: Paz e Terra, 1977.

HOBSBAWM, Eric. Nações e Nacionalismo desde 1780. $5^{\text {a }}$ ed. São Paulo: Paz e Terra, 2008.

HOBSBAWM, Eric. Globalização, Democracia e Terrorismo. São Paulo: Cia. das Letras, 2007

HUNTINGTON, Samuel. O Choque de Civilizações e a recomposição da Ordem Mundial. Rio de Janeiro: Objetiva, 1997.

KENNEDY, Paul. Preparando para o século XXI. Rio de Janeiro: Campus, 1993.

KENNEDY, Paul. Ascensão e queda das grandes potências. Rio de Janeiro: Campus, 1988.

LAQUEUR, Walter. Os últimos dias da Europa: Epitáfio para um velho continente. Rio de Janeiro: Odisséia, 2007. 
MARTINS, Estevão C. R. Prefácio: História das Relações Internacionais contemporâneas. São Paulo: Saraiva; Brasília: IBRI, 2008.

MATEO, Luiza R. Deus abençoe a América: religião, política e relações internacionais dos Estados Unidos. São Paulo:

UNESP-UNICAMP-PUC-SP, Dissertação de Mestrado em Relações Internacionais, 2011.

MEDEIROS, Marcelo A., VILlA, Rafael. D. et al. (Org.). Clássicos das Relações Internacionais. São Paulo: Hucitec, 2010.

MINC, Alain. A nova Idade Média. São Paulo: Ática, 1994.

ORO, Ari P.; STEIL, Carlo A.(Org.). Globalização e Religião. 2ª ed. Petrópolis: Vozes, 1999.

PIERUCCI, Antonio Flávio. O Desencantamento do Mundo. Todos os passos do conceito em Max Weber. São Paulo: Ed. 34, 2003.

PIERUCCI, Flávio \& PRANDI, Reginaldo. A realidade social das religiões no Brasil. São Paulo: Hucitec, 1996.

RAFFEStin, Claude. Por uma Geografia do Poder. São Paulo: Ática, 1993.

RAMONET, Ignácio. Geopolítica do caos. Petrópolis: Vozes, 1998.

RESENDE, Erica S. A. Americanidade, Puritanismo e Política Externa: a (re)produção da ideologia puritana e a construção da identidade nacional nas práticas discursivas da política externa norte-americana. São Paulo: USP-FFLCH, Ciência Política. Tese Doutorado, 2009, p.334.

RIBEIRO, Wagner C. Ordem Ambiental Internacional. São Paulo: Contexto, 2001.

ROMAnO, Roberto. A Paz da Westfália (1648). IN: MAGNOLI, Demétrio (Org.). História da Paz. São Paulo: Contexto, 2008, pp. 69-92.

ROSENAU, James et al. (Org.). Governança sem governo: ordem e transformação na política mundial. Brasilia:UnB; São Paulo: Imprensa Oficial, 2000.

SANTOS, Alberto P. Novas geopolíticas, Igrejas e População sem Religião: anarquia religiosa no Brasil?. Revista GEOUSP, São Paul, n. 33, 2013.

SANTOS, Alberto P. Geoética e Relações Internacionais. Rio de Janeiro: Revista GeoUERJ, Ano 14, nํ․ 24, v. 2, 2ํำ semestre de 2012, p. 479-508.

SANTOS, Alberto P. Geopolitica das Igrejas e Anarquia Religiosa no Brasil: Por uma Geoética de Apoio Mútuo. São Paulo: USP, FFLCH, Depto. Geografia, Tese Doutorado, 2011.

SANTOS, Alberto P. Introdução à Geografia das Religiões. São Paulo: Revista GEOUSP, n. 11, 2002, pp. 21-33.

SANTOS, Milton. Por uma outra globalização. 9ª ed. Rio de Janeiro; São Paulo: Record, 2002.

SARAIVA, J. ; Flávio S. (Org.). História das Relações Internacionais Contemporâneas: da sociedade internacional do século XIX à era da globalização. 2ª . ed. São Paulo: Saraiva; Brasília: IBRI, 2008.

VESENTINI, J. William. Nova Ordem, Imperialismo e Geopolítica Global. Campinas: Papirus, 2003.

VESENTINI, J. Novas Geopoliticas. São Paulo: Contexto, 2000.

WALLERSTEIN, Immanuel. Geopolitics and geoculture. Nova York: Cambridge University Press, 1991. 
WEBER, Max. A Ética Protestante e o Espírito do Capitalismo. São Paulo: Martin Claret, 2004.

WEBER, Max. Sociologia da Religião. In: WEBER, Max. Economia e Sociedade. Brasília: UNB, 1984. 